\title{
Turtle shell bone and osteoderm histology of Mesozoic and Cenozoic stem-trionychian Adocidae and Nanhsiungchelyidae (Cryptodira: Adocusia) from Central Asia, Mongolia, and North America
}

\author{
Torsten M. Scheyer ${ }^{1}$, Elena V. Syromyatnikova ${ }^{2,3}$, and Igor G. Danilov ${ }^{3,4}$ \\ ${ }^{1}$ University of Zurich, Palaeontological Institute and Museum, Karl Schmid-Strasse 4, 8006 Zurich, Switzerland \\ ${ }^{2}$ A. A. Borissiak Paleontological Institute, Russian Academy of Sciences, 123, Profsoyuznaya ul., Moscow, 117997, Russia \\ ${ }^{3}$ Zoological Institute of the Russian Academy of Sciences, Universitetskaya Emb 1, St. Petersburg, 199034, Russia \\ ${ }^{4}$ Department of Vertebrate Zoology, Saint Petersburg State University, Universitetskaya Emb. 7/9, St. Petersburg, 199034, \\ Russia
}

Correspondence to: Torsten M. Scheyer (tscheyer@pim.uzh.ch)

Received: 15 December 2016 - Accepted: 17 January 2017 - Published: 3 February 2017

\begin{abstract}
The record of fossil turtles from the Cretaceous and Cenozoic of Asia and North America is very rich, including several lineages of cryptodiran turtles. Here we survey the shell bone histology of two important closely related groups of stem trionychians, the Adocidae and Nanhsiungchelyidae, which have representatives in both Asia and North America. All studied taxa show shell bones in which the diploe is framed by well-developed cortical compact bone layers. Taxa of both groups also express external regular surface sculpturing of their shell bones, and in the case of the nanhsiungchelyid genus Basilemys also on the osteoderms, which is also reflected in the internal histological bone structures. Besides similarities of the regular ornamentation patterns, both groups share a number of microanatomical and histological characters such as the zonation of external cortex with rather homogeneous fine-fibred interwoven structural fibres (ISF) in the more internal zone and a dominance of vertically oriented fibres in the ISF and the presence of growth marks in the more external zone. On the other hand, growth marks, i.e. lines of arrested growth, which are visible as wavy lines in thin sections, extend subparallel to the external bone surface in adocids, but they are not parallel/subparallel in nanhsiungchelyids. Thickness and structure of bone trabeculae in the cancellous interior regions depends on the shell bone thickness of the individual samples. The internal cortices of all taxa except the North American samples of Adocus usually consist of parallel-fibred bone that locally grades into lamellar bone. Secondary bone remod-
\end{abstract}

elling is more frequent in nanhsiungchelyids compared to adocids, and Sharpey's fibres that extend perpendicular to the bone margins extending across subparallel growth marks are more commonly found in adocids. In addition, bone histology served to identify trionychid specimens in the adocid and nanhsiungchelyid samples, especially as bone surface sculpturing patterns were weathered or eroded in those cases. The histological data present thus supplement the numerous previously reported differences in external shell morphology between adocids and nanhsiungchelyids on the one hand and trionychids and carettochelyids on the other.

\section{Introduction}

The fossil record from the Cretaceous and Cenozoic of Asia and North America includes several lineages of cryptodiran turtles (Hutchison, 2000; Sukhanov, 2000). There are two important closely related clades of stem trionychians, which have representatives in the Mesozoic and the Cenozoic, in both Asia and North America: (1) Adocidae Cope, 1870, including medium to large freshwater forms from the Cretaceous and Palaeogene, and (2) Nanhsiungchelyidae Yeh, 1966, turtles peculiar by a combination of aquatic and terrestrial features (see Danilov and Syromyatnikova, 2008, 2009a, b; Danilov et al., 2011). Both Adocidae and Nanhsiungchelyidae comprise the clade Adocusia (sensu Danilov and Parham, 2006; Danilov and Syromyatnikova, 2009a, 
b), which, together with Peltochelyidae Seeley, 1880 from the Early Cretaceous of Europe, belong to the stem of Trionychia Hummel, 1929. The phylogenetic analyses that do not support the clade Adocusia still place Adocidae and Nanhsiungchelyidae at the stem of Trionychia (Tong et al., 2009, 2014). Trionychia, on the other hand, consists of the two crown clades: Trionychidae Gray, 1825 and PanCarettochelys Joyce et al., 2004 (which corresponds to the family Carettochelyidae Boulenger, 1887 under traditional nomenclature), with stem representatives of both groups also reaching back into the Early Cretaceous of Asia (Danilov and Vitek, 2013; Hirayama et al., 2013; Joyce, 2014).

According to the previous phylogenetic analyses (Danilov and Syromyatnikova, 2009a, b), Adocidae first appeared in the Late Jurassic of Asia and persisted there until the Oligocene (e.g. Nessov, 1977; Chkihkvadze, 1990; Danilov et al., 2011; Syromyatnikova, 2011), whereas the adocid record in North America spans the period between the Turonian/Coniacian until the end of the Palaeocene (e.g. Hutchison, 2000). Other phylogenetic studies consider the Late Jurassic record outside Adocidae (Tong et al., 2014; see below). As noted in a recent review of the Asian nanhsiungchelyid fossil record (Danilov and Syromyatnikova, 2008), the group is known from the Barremian-Aptian to the Maastrichtian in Asia, whereas the North American record extends from the Coniacian/Santonian to the Maastrichtian (Hutchison, 2000; Hirayama, 2002).

According to Danilov and Syromyatnikova (2009a, b), Adocidae includes Yehguia tatsuensis (Yeh, 1963) (current name Sinaspideretes wimani Young and Chow, 1953, sometimes excluded from Adocidae; see Tong et al., 2014; Joyce et al., 2016) and two clades: Adocinae Cope, 1870, with a single genus, Adocus Cope, 1868 ( = Adocoides Sukhanov and Narmandakh, 2006; = Shineusemys Sukhanov and Narmandakh, 2006; see Syromyatnikova et al., 2012, 2013), and Shachemydinae Khosatzky in Nessov and Khosatzky (1977), with the genera Shachemys Kuznetsov, 1976 and Ferganemys Nessov and Khosatzky, 1977 (see Syromyatnikova, 2011). Of those, Adocus is the only taxon encountered in both Asia and North America (Danilov et al., 2011). The skeletal morphology of Adocus has been extensively described (Meylan and Gaffney, 1989), whereas a revision of the genus Adocus from the Late Cretaceous of Asia was given more recently (Syromyatnikova and Danilov, 2009, 2013; Syromyatnikova et al., 2012, 2013). In addition, the first truly identifiable Adocus material from the Palaeogene of Asia was described, together with a comparison of surface sculpture patterns in the genus, as Adocus inexpectatus Danilov et al., 2013 (Danilov et al., 2013b).

Nanhsiungchelyidae includes the genera Anomalochelys Hirayama et al., 2001; Basilemys Hay, 1902; Hanbogdemys Sukhanov and Narmandakh, 2006 (= Bulganemys Sukhanov and Narmandakh, 2006; see Danilov and Syromyatnikova, 2008); Jiangxichelys Tong and Mo, 2010; Kharakhutulia Sukhanov et al., 2008; Nanhsiungchelys Yeh, 1966, Yuchelys
Tong et al., 2012; and Zangerlia Młynarski, 1972 (e.g. Młynarski, 1972; Brinkman and Nicholls, 1993; Brinkman and Peng, 1996; Hirayama et al., 2001; Joyce and Norell, 2005; Sukhanov and Narmandakh, 2006; Danilov and Syromyatnikova, 2008; Sukhanov et al., 2008; Tong and Mo, 2010; Tong et al., 2012; Danilov et al., 2013a; Brinkman et al., 2015). Of those taxa, Basilemys is present only in North America (Hutchison, 2000).

Here we present comparative histological data on members of the group of Adocidae and Nanhsiungchelyidae from Central Asia, Mongolia, and North America to elucidate whether there are group-specific shell bone microstructures. Thus, the current study uses the phylogenetic working hypothesis of Syromyatnikova et al. (2013: fig. 14) as a framework. The samples have been chosen to cover as much of the taxonomic breadth of both groups as possible. Preliminary histological results of the adocid and nanhsiungchelyid shell bones from North America have already been reported in Scheyer (2007) and Scheyer and Anquetin (2008), and those from Asia and North America by Syromyatnikova et al. (2016).

\section{Materials and methods}

\subsection{General aspects}

All specimens used in this study were embedded in synthetic resin prior to sampling. Thin sections were produced following standard procedures for the preparation of petrographic thin sections (see Scheyer et al., 2007). Turtle shell bone and histological terminology is following FrancillonVieillot et al. (1990), Scheyer and Sánchez-Villagra (2007), and Scheyer et al. (2007). The thin sections were then studied using a Leica DM2500M composite microscope equipped with a Leica DFC420C digital camera.

A complete list of specimens used in this study, including more detailed data on localities, ages, and accession numbers, has been compiled in Table 1. Several specimens assigned to Adocidae and Nanhsiungchelyidae prior to this study (Danilov and Syromyatnikova, 2008; Danilov et al., 2011) appeared to be representatives of Trionychidae (see Sect. 3.3 and 3.4 below).

\subsection{Adocidae from Central Asia and Mongolia}

The sample of Central Asian and Mongolian shell material assigned to Adocidae includes costal fragments of Adocus aksary Nessov in Nessov and Krasovskaya, 1984 (late Turonian Bissekty Formation, Uzbekistan); A. bostobensis Syromyatnikova and Danilov, 2009 (Santonian-early Campanian Bostobe Formation, Kazakhstan); A. foveatus Nessov and Khosatzky in Khosatzky and Nessov, 1977 (early Santonian Yalovach Formation, Tajikistan); and A. kizylkumensis Nessov, 1981 (early Cenomanian Khodzhakul Formation, Uzbekistan), a peripheral from Adocus sp. (late Oligocene 
Table 1. Locality information and accession numbers of specimens used in the study.

\begin{tabular}{|c|c|}
\hline No. & Specimens \\
\hline \multicolumn{2}{|c|}{ Central Asia and Mongolia Adocidae } \\
\hline 1 & $\begin{array}{l}\text { Adocus aksary Nessov in Nessov and Krasovskaya, } 1984 \\
\text { ZIN PH 182/84, fragment of costal; Dzharakuduk locality, central Kyzylkum, Uzbekistan; Bissekty Formation, late Turonian. }\end{array}$ \\
\hline 2 & $\begin{array}{l}\text { Adocus bostobensis Syromyatnikova and Danilov, } 2009 \\
\text { ZIN PH 16/94, fragment of costal; Baybishe locality, Aral Sea area, Kazakhstan; Bostobe Formation, Santonian-early Campanian. }\end{array}$ \\
\hline 3 & $\begin{array}{l}\text { Adocus dzhurtasensis Syromyatnikova and Danilov, } 2009 \\
\text { ZIN PH 92, shell fragment; Dzhurtas locality, Dzhungar Alatau Ridge, south-eastern Kazakhstan; Santonian-early Campanian. }\end{array}$ \\
\hline 4 & $\begin{array}{l}\text { Adocus foveatus Nessov and Khosatzky in Nessov and Khosatzky, } 1977 \\
\text { ZIN PH 593/64, fragment of costal; Kansai locality, Fergana Depression, Tajikistan; Yalovach Formation, early Santonian. }\end{array}$ \\
\hline 5 & $\begin{array}{l}\text { Adocus kizylkumensis Nessov, } 1981 \\
\text { ZIN PH 21/87, fragment of costal; Khodzhakul locality, Sultanuvais Range, Uzbekistan; lower part of the Khodzhakul Formation, early } \\
\text { Cenomanian. }\end{array}$ \\
\hline 6 & $\begin{array}{l}\text { Adocus sp. } \\
\text { ZIN PH 3/93, shell fragment (peripheral); Aktau locality, Ily Basin, south-eastern Kazakhstan; Aktau Formation, late Oligocene. }\end{array}$ \\
\hline 7 & $\begin{array}{l}\text { Adocus sp. } \\
\text { ZIN PH 2/91, shell fragment; Tsagan Teg, Umnegov Aimag, Mongolia; upper part Bainshire Formation, late Turonian-Santonian. }\end{array}$ \\
\hline 8 & $\begin{array}{l}\text { Adocus sp. } \\
\text { ZIN PH 6/80, fragment of hypoplastron; Khara Khutul locality, Dornogov Aimag, Mongolia; lower part of the Bainshire Formation, } \\
\text { Cenomanian-early Turonian. }\end{array}$ \\
\hline 9 & $\begin{array}{l}\text { Ferganemys itemirensis Nessov, } 1981 \\
\text { ZIN PH 84/87, fragment of costal 6; Sheikhdzheili II and Khodzhakulsay localities, Sultanuvais Range, Uzbekistan; Khodzhakul } \\
\text { Formation, early Cenomanian. }\end{array}$ \\
\hline 10 & $\begin{array}{l}\text { Ferganemys itemirensis Nessov, } 1981 \\
\text { ZIN PH 37/86, fragment of plastron; Itemir locality, central Kyzylkum, Uzbekistan; Orazalin, Kulbikin, Itemir, Bortesken, and } \\
\text { Dzharakuduk members, Cenomanian. }\end{array}$ \\
\hline 11 & $\begin{array}{l}\text { Ferganemys verzilini Nessov and Khosatzky, } 1977 \\
\text { ZIN PHT F67, fragment of costal; Kylodzhun I locality, south-eastern Fergana, Kyrgyzstan; upper part of the Alamyshyk Formation, } \\
\text { late Albian. }\end{array}$ \\
\hline 12 & $\begin{array}{l}\text { Shachemys ancestralis Nessov in Nessov and Krasovskaya, } 1984 \\
\text { ZIN PH 12, fragment of costal; Dzharakuduk locality, central Kyzylkum, Uzbekistan; Bissekty Formation, late Turonian. }\end{array}$ \\
\hline 13 & $\begin{array}{l}\text { Shachemys baibolatica Kuznetsov, } 1976 \\
\text { ZIN PH 64, fragment of costal; Kansai locality, Fergana Depression, Tajikistan; Yalovach Formation, early Santonian. }\end{array}$ \\
\hline 14 & $\begin{array}{l}\text { Shachemys sp. } \\
\text { ZIN PH 2/116, fragment of xiphiplastron; Daugyztau I locality, central Kyzylkum, Uzbekistan; late Turonian-Coniacian. }\end{array}$ \\
\hline \multicolumn{2}{|c|}{ Central Asia and Mongolia Nanhsiungchelyidae } \\
\hline 15 & $\begin{array}{l}\text { Hanbogdemys orientalis (Sukhanov and Narmandakh, 1975) } \\
\text { PIN 3458, shell fragment; Bayshin Tsav locality, Dornogov Aimag, Mongolia; upper part of the Bainshire Formation, late Turonian- } \\
\text { Santonian. }\end{array}$ \\
\hline 16 & $\begin{array}{l}\text { Kharakhutulia kalandadzei Sukhanov et al., } 2008 \\
\text { PIN 5268, fragment of costal 1; Khara Khutul locality, Dornogov Aimag, Mongolia; lower part of the Bainshire Formation, } \\
\text { Cenomanian-early Turonian. }\end{array}$ \\
\hline 17 & $\begin{array}{l}\text { Nanhsiungchelyidae indet. } \\
\text { ZIN PH 38/80, fragment of costal; Khara Khutul locality, Dornogov Aimag, Mongolia; lower part of the Bainshire Formation, } \\
\text { Cenomanian-early Turonian. }\end{array}$ \\
\hline
\end{tabular}


Table 1. Continued.

\begin{tabular}{|c|c|}
\hline No. & Specimens \\
\hline 18 & $\begin{array}{l}\text { Nanhsiungchelyidae indet. } \\
\text { ZIN PH 101/10, shell fragment; Shakh-Shakh locality, Aral Sea area, Kazakhstan; Bostobe Formation, Santonian-early Campanian. }\end{array}$ \\
\hline 19 & $\begin{array}{l}\text { Nanhsiungchelyidae indet. } \\
\text { ZIN PH 11/103, shell fragment; Khamaryn Khural locality, Dornogov Aimag, Mongolia; Hühteeg Svita, Aptian-Albian. }\end{array}$ \\
\hline 20 & $\begin{array}{l}\text { Nanhsiungchelyidae indet. } \\
\text { ZIN PH 10/87, fragment of costal; Sheikhdzheili II and Khodzhakulsay localities, Sultanuvais Range, Uzbekistan; Khodzhakul Forma- } \\
\text { tion, early Cenomanian. }\end{array}$ \\
\hline \multicolumn{2}{|c|}{ North America Adocidae } \\
\hline 21 & $\begin{array}{l}\text { Adocus sp. } \\
\text { UCMP V73096/150202, neural; Tullock Fm., Garfield County, Montana, USA; early Palaeocene (Puercan). }\end{array}$ \\
\hline 22 & $\begin{array}{l}\text { Adocus sp. } \\
\text { UCMP V87101/150200, proximal fragment of costal; Hell Creek Fm., McCone County, Montana, USA; early Palaeocene (Puercan). }\end{array}$ \\
\hline 23 & $\begin{array}{l}\text { Adocus sp. } \\
\text { UCMP V87101/150201, distal fragment of peripheral; Hell Creek Fm., McCone County, Montana, USA; early Palaeocene (Puercan). }\end{array}$ \\
\hline 24 & $\begin{array}{l}\text { Adocus sp. } \\
\text { UCMP V87071/150192, fragment of plastron (?hyo- or hypoplastron); Hell Creek Fm., McCone County, Montana, USA; early } \\
\text { Palaeocene (Puercan). }\end{array}$ \\
\hline 25 & $\begin{array}{l}\text { Adocus sp. } \\
\text { PIMUZ A/III 4461, proximal part of right costal } 2 \text { and a neural 2; Hell Creek Fm. (Lancian, Late Cretaceous), Turtle Graveyard locality, } \\
\text { Slope County, North Dakota, USA }\end{array}$ \\
\hline \multicolumn{2}{|c|}{ North America Nanhsiungchelyidae } \\
\hline 26 & $\begin{array}{l}\text { Basilemys sp. } \\
\text { FM P27371, fragment of two sutured peripherals; McKinley County, New Mexico, USA; Kirtland Shale, Late Cretaceous }\end{array}$ \\
\hline 27 & $\begin{array}{l}\text { Basilemys sp. } \\
\text { FM P27371, fragment of shell periphery; McKinley County, New Mexico, USA; Kirtland Shale, Late Cretaceous }\end{array}$ \\
\hline 28 & $\begin{array}{l}\text { Basilemys sp. } \\
\text { FM P27371, indeterminate shell fragment with suture; McKinley County, New Mexico, USA; Kirtland Shale, Late Cretaceous }\end{array}$ \\
\hline 29 & $\begin{array}{l}\text { Basilemys sp. } \\
\text { FM P27371, fragment of plastron (?hyo- or hypoplastron); McKinley County, New Mexico, USA; Kirtland Shale, Late Cretaceous }\end{array}$ \\
\hline 30 & $\begin{array}{l}\text { Basilemys sp. } \\
\text { YPM 9703, peripheral; Schneider Cn., Converse County, Wyoming, USA; Laramie Beds, Cretaceous; formerly accessioned as "Adocus } \\
\text { vigoratus" }\end{array}$ \\
\hline 31 & $\begin{array}{l}\text { Basilemys sp. } \\
\text { TMP 2003.12.278, ridged osteoderm with three spikes; Dinosaur Provincial Park, Alberta, Canada; Belly River Group, Late Cretaceous }\end{array}$ \\
\hline 32 & $\begin{array}{l}\text { Basilemys sp. } \\
\text { TMP 80.08.296, single spiked osteoderm; Dinosaur Provincial Park, Alberta, Canada; Oldman or Dinosaur Park Fm., Belly River } \\
\text { Group, Late Cretaceous }\end{array}$ \\
\hline 33 & $\begin{array}{l}\text { Basilemys sp. } \\
\text { PIMUZ A/III 4460, costal fragment; Hell Creek Fm. (Lancian, Late Cretaceous), Turtle Graveyard locality, Slope County, North Dakota }\end{array}$ \\
\hline \multicolumn{2}{|c|}{ Central Asia and Mongolia Trionychidae } \\
\hline 34 & $\begin{array}{l}\text { Trionychidae indet. } \\
\text { ZIN PH 3/75 and 4/75, shell fragments; Kalmakpay locality, Zaisan Depression, eastern Kazakhstan; Obayla Formation, middle Eocene. }\end{array}$ \\
\hline 35 & $\begin{array}{l}\text { Trionychidae indet. } \\
\text { ZIN PH 11/101, fragment of costal; Dzun Bayan locality, Dundgov Aimag, Mongolia; Baruunbayan Svita, Aptian-Albian. }\end{array}$ \\
\hline
\end{tabular}


Aktau Formation, Kazakhstan), a fragmentary hypoplastron from Adocus sp. (Cenomanian-early Turonian lower part of the Bainshire Formation, Mongolia), and indeterminate shell fragments of A. dzhurtasensis Syromyatnikova and Danilov, 2009 (Santonian-early Campanian, Kazakhstan), "Adocus" kazachstanica Chkhikvadze, 1973 (middle Eocene Obayla Formation, Kazakhstan), and Adocus sp. (late TuronianSantonian upper part of the Bainshire Formation, Mongolia). Furthermore the sample included a fragment of costal 6 and a plastral fragment of "Ferganemys" itemirensis Nessov, 1981 (early Cenomanian Khodzhakul Formation and Cenomanian Bortesken and Dzharakuduk members, Uzbekistan); a costal fragment of Ferganemys verzilini Nessov and Khosatzky, 1977 (late Albian Alamyshyk Formation, Kyrgyzstan); costal fragments of Shachemys ancestralis Nessov in Nessov et Krassovskaya, 1984 (late Turonian Bissekty Formation, Uzbekistan) and S. baibolatica Kuznetsov, 1976 (early Santonian Yalovach Formation, Tajikistan); and a fragment of a xiphiplastron of Shachemys sp. (late TuronianConiacian, Daugyztau I locality, Uzbekistan).

\subsection{Nanhsiungchelyidae from Central Asia and Mongolia}

The sample of Central Asian and Mongolian shell material from the Cretaceous assigned to Nanhsiungchelyidae includes a shell fragment of Hanbogdemys orientalis (Sukhanov and Narmandakh, 1975) (late TuronianSantonian upper part of the Bainshire Formation, Mongolia), a fragment of costal 1 and four peripheral fragments of Kharakhutulia kalandadzei Sukhanov et al., 2008 (Cenomanian-early Turonian lower part of the Bainshire Formation, Mongolia), and five specimens identified as Nanhsiungchelyidae indet.: three costal fragments (Cenomanian-early Turonian lower part of the Bainshire Formation, Mongolia; Aptian-Albian Baruunbayan Svita, Mongolia; early Cenomanian Khodzhakul Formation, Uzbekistan) and two indeterminate shell fragments (Santonian-early Campanian Bostobe Formation, Kazakhstan; Aptian-Albian Hühteeg Svita, Mongolia). The sampled specimens listed here show a sculpturing pattern of large, irregular grooves and pits of the external bone surface (termed "nanhsiungchelyid sculpturing" by Danilov and Syromyatnikova, 2008) reminiscent of the "pock-mark" pattern described for Basilemys (see Młynarski, 1976), although the sculpturing appears more pronounced in the North American taxon.

\subsection{Adocidae from North America}

Of North American Adocidae, material of Adocus was sampled, including a neural and fragments of a costal, a peripheral and plastron (hyo- or hypoplastron) from the early Palaeocene Tullock and Hell Creek formations (Puercan) of Montana, USA. In addition, Adocus sp. from the Hell Creek
Formation (Lancian, Late Cretaceous) at the Turtle Graveyard locality in Slope County, North Dakota, USA, was sampled, including a proximal part of right costal 2 and neural 2.

\subsection{Nanhsiungchelyidae from North America}

The studied material of Basilemys included a pair of sutured peripherals, a plastral fragment (?hyo- or hypoplastron), and two indeterminate marginal shell fragments (all FM P27371), all found in the Late Cretaceous Kirtland Shale of New Mexico, USA. Further shell material included a large isolated peripheral (YPM 9703) from the Cretaceous Laramie Beds of Wyoming, USA, as well as two osteoderms (TMP 2003.12.278; TMP 80.08.296) from the Oldman or Dinosaur Park formations, Belly River Group of Alberta, Canada (see Eberth, 2005). The exact location of the osteoderms on the body is unknown. In addition, a single costal fragment of Basilemys sp. from the Hell Creek Formation (Lancian, Late Cretaceous) from Turtle Graveyard locality (Slope County, North Dakota, USA) was sampled as well.

\subsection{Institutional abbreviations}

FM, The Field Museum, Chicago, Illinois, USA; PIN, A.A. Borissiak Paleontological Institute, Russian Academy of Sciences, Moscow, Russia; TMP, Royal Tyrrell Museum of Palaeontology, Drumheller, Canada; UCMP, Museum of Paleontology, University of California at Berkeley, California, USA; YPM, Yale Peabody Museum of Natural History, New Haven, Connecticut, USA; ZIN PH, Paleoherpetological collection, Zoological Institute, Russian Academy of Sciences, St. Petersburg, Russia.

\section{Histological results}

\subsection{Adocidae}

All specimens studied show a well-developed diploe with equally thick external and internal compact cortical bone framing an area of interior cancellous bone (Figs. 1, 2). In transverse sections (here referred to as X sections), the bone appears generally less compact than in the longitudinal sections (or L sections), partly because of the lateral bone sutures and associated vascular spaces. This is confirmed by those specimens, which were sampled in perpendicularly arranged planes of sectioning (e.g. ZIN PH 84/87; UCMP V87101/150200). In the case of ZIN PH 3/93 (Adocus sp.), the internal compacta shares the same bone tissue structure as is typical for the external compact bone layers; therefore, the specimen is interpreted as a fragment of a peripheral. A general adocid morphotype as described below was found in all adocid specimens studied. 

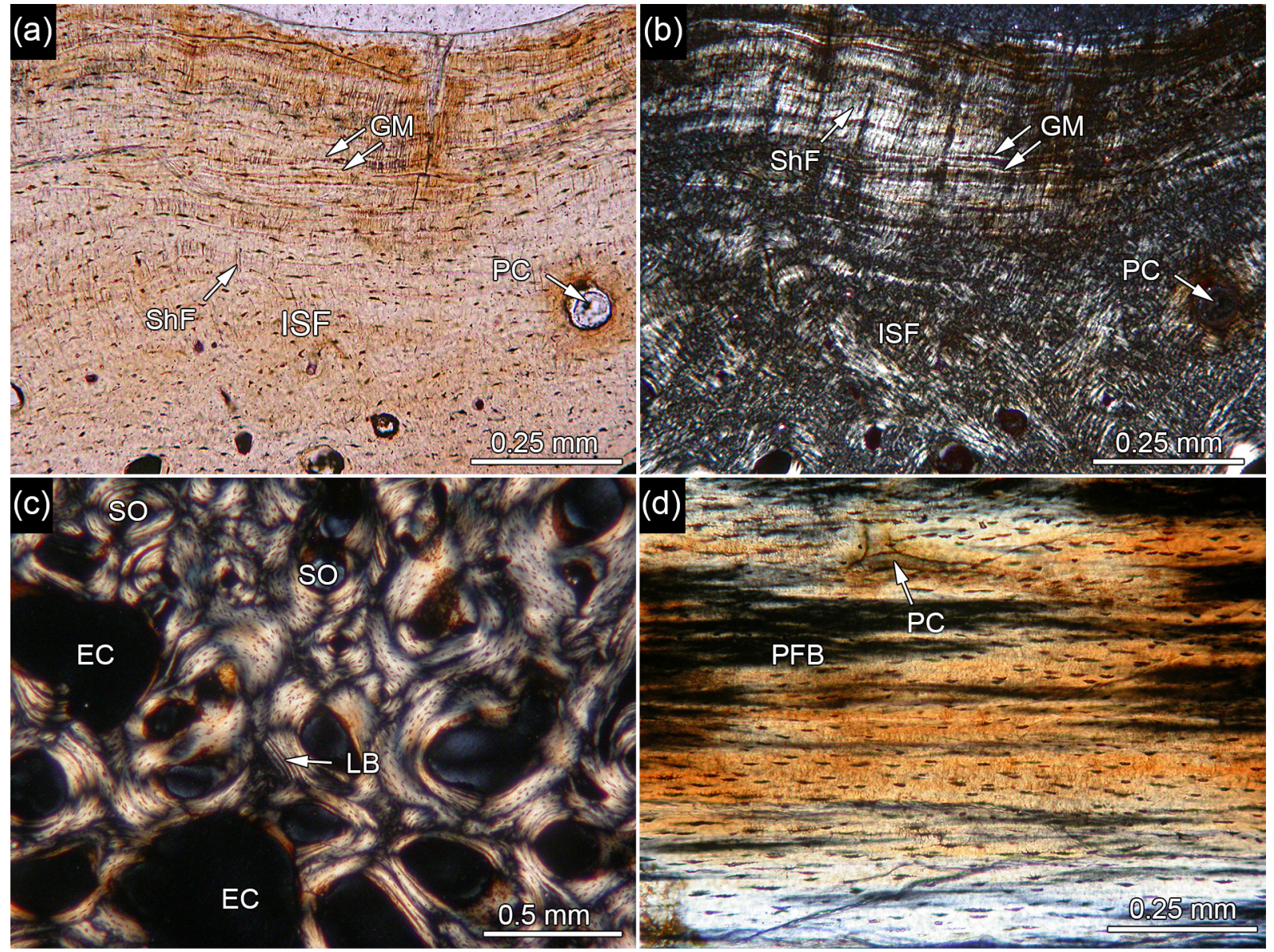

Figure 1. Shell bone histology of Adocus sp. from North America. Image (a) is in normal transmitted light, and images (b-d) are in polarised light. Close-up of the interwoven structural fibre bundles of external cortex of the peripheral UCMP V87101/150201. (a, b) Note presence of growth marks and perpendicular fibre bundles in the more external zone. The more internal zone shows fine-fibred homogeneous structure of the ISF. (c) Close-up of interior trabecular and coarse cancellous bone of the costal UCMP V87101/150200. (d) Close-up of parallel-fibred bone of internal cortex of the costal UCMP V87101/150200. The bone tissue is vascularised by few scattered primary vascular canals only. Abbreviations: EC, erosion cavities; GM, growth mark; ISF, interwoven structural fibre bundles; LB, lamellar bone; PC, primary vascular canal; PFB, parallel-fibred bone; SO, secondary osteon.

\subsubsection{External cortex}

The external cortex is divided into a more external zone and a more internal zone bordering the cancellous bone. The more internal zone is built of interwoven structural fibres (ISF), where fine fibre bundles extend equally diagonally, perpendicular and subparallel to the external bone surface (Fig. 1a, b). This zone is also characterised by an extensive and welldeveloped reticular system of primary vascular canals. The reticular system (Fig. 2a) is most strongly developed towards the lateral bone sutures (e.g. ZIN PH 84/87, "Ferganemys" itemirensis). In the more external zone, the fibre bundles that extend perpendicular to the external bone surface become increasingly dominant in the ISF. Growth marks seen in this zone are highly birefringent in polarised light (Fig. 2b) and have a wavy character, thus extending subparallel to the external surface of the bones. This zone consists mostly of avas- cular bone layers, with the exception of a few isolated larger vascular canals exiting on the external bone surface as foramina and scattered primary and, to a lesser degree, secondary osteons. Based on the variable stages of preservation of the shell elements, the thickness of the more external zone of the cortex varies greatly. Scattered secondary osteons and secondary osteon clusters are frequently found at the transition to the cancellous bone. In ZIN PH 92 (Adocus dzhurtasensis), only a single bone tissue - i.e. ISF vascularised by a strong reticular vascularisation pattern with many canals opening up to the external bone surface but lacking any wavy highly birefringent growth marks - is present (Fig. 2c). This tissue type is typically found in the more internal zone of the external cortex but, because of the strong degree of erosion, constitutes the outer bone surface in this specimen. 

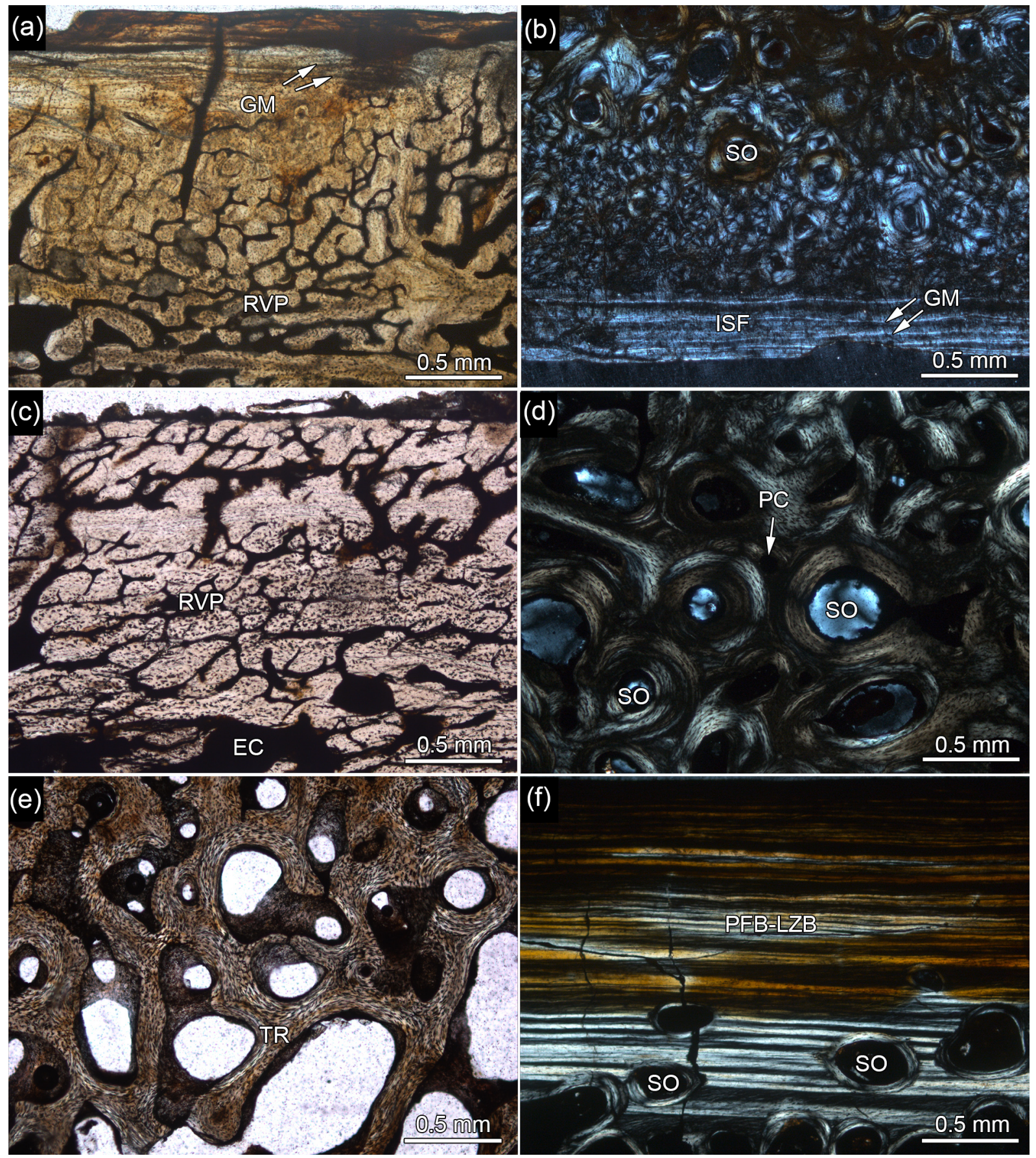

Figure 2. Bone histology of Adocidae from Central Asia and Mongolia. Images (a), (c), and (e) are in normal transmitted light, images (b), (d), and (f) in polarised light. (a) Close-up of the external cortex of ZIN PH 84/87 ("Ferganemys" itemirensis). Growth marks are visible in the more external zone, whereas the more internal zone is dominated by an extensive reticular vascularisation pattern. (b) Close-up of the external cortex of ZIN PH 2/116 (Shachemys sp., xiphiplastron: external bone surface is in lower part of image). The more external zone shows highly birefringent growth marks, whereas the more internal zone is increasingly remodelled by secondary osteons. (c) Close-up of the external cortex of ZIN PH 92 (Adocus dzhurtasensis). Note absence of the more external zone. (d) Interior coarse cancellous bone of ZIN PH 593/64 (Adocus foveatus). (e) Close-up of the interior trabecular bone of ZIN PH 2/91 (Adocus sp.). (f) Close-up of the internal cortex of ZIN PH 37/86 ("Ferganemys" itermirensis, plastron fragment) showing parallel-fibred bone grading into lamellar bone. Note the light and dark extinction pattern of the tissue. Abbreviations: EC, erosion cavities; GM, growth mark; ISF, interwoven structural fibre bundles; PFBLZB, parallel-fibred bone-lamellar zonal bone; PC, primary vascular canal; RVP, reticular vascularisation pattern; SO, secondary osteon; TR, trabecular bone. 


\subsubsection{Cancellous bone}

The cancellous bone is dominated by short and thick trabeculae, in various stages of remodelling (Figs. 1c, 2d), delimiting mostly round to ovoid intertrabecular spaces or, as in ZIN PH 593/64, coarse cancellous bone. Primary ISF are present in most trabeculae, as well as in trabecular branching areas. In the thicker bones, the bone trabeculae were more slender and longer (Fig. 2e), but interstitial primary bone tissue may still be present. The walls of the trabeculae comprise secondary lamellar bone, although there are also erosion cavities in the trabecular meshwork that still lack the secondary bone deposition. Erosion bays and scattered secondary osteons are frequently encountered towards the external and internal cortices.

\subsubsection{Internal cortex}

The internal cortical bone (Figs. 1d, 2f) consists of parallelfibred bone (PFB), which, as seen in most of the Asian taxa (e.g. Adocus aksary, Shachemys spp., Ferganemys verzilini and "F." itemirensis), can grade into lamellar zonal bone (LZB), as indicated by closely spaced changes in extinction of adjacent layers which cause a light and dark banding (well visible also in the specimens assigned to "A." kazachstanica). This grading into lamellar bone, similar to what has been described previously in the pleurodiran Podocnemis erythrocephala (de Spix, 1824) (see Scheyer and Sánchez-Villagra, 2007), was not recognised in the North American sample of Adocus sp. Adjacent to the cancellous interior, the tissue is vascularised with few scattered primary vascular canals and primary osteons, which, as in ZIN PH 84/87, are more circular to ovoid in the $\mathrm{L}$ section and more oblong to elongate in the $\mathrm{X}$ section. Close to the cancellous bone, larger erosion bays and secondary osteons are scattered through the tissue as well. Sharpey's fibres were found in the internal cortices of the bones, especially in the plastral fragments and the costal fragments, which show a distinct rib bulge.

\subsubsection{Sutures}

The sutured margins are generally well developed. Long fibre bundles, i.e. Sharpey's fibres that extend perpendicular to the margins of the bones, are found throughout the bone tissue constituting the margins. The bone tissue itself resembles the one described for the more external zone of the external cortex. Indeed, the growth marks can often be followed from the external cortex towards the sutured margins, where they extend subparallel to the outer bone surface.

\subsection{Nanhsiungchelyidae}

The shell bones of the nanhsiungchelyids sampled have a diploe structure, with cortical bone layers framing the interior cancellous bone (Figs. 3, 4). A highly organised "spindle-shaped pattern" of ornamentation is restricted to the sample of Basilemys sp. from North America (Fig. 4). The external cortex structure of Basilemys sp. was already figured in a comparative study of turtle shell material of the Kirtlington microvertebrate site (Bathonian, Middle Jurassic), Oxfordshire, UK (Scheyer and Anquetin, 2008). The sampled osteoderms of Basilemys sp. share many histological features with the shell bones, but there are also a few differences, which will be mentioned separately below. In the case of Kharakhutulia kalandadzei (PIN 5268), all bone samples were strongly subjected to diagenetic alteration, and thus only few histological details were observable. In all specimens only the diploe, as well as parallel-fibred bone of the internal cortex and a reticular vascularisation pattern in the external cortical bone, was visible. All other histological details were obscured. The information based on K. kalandadzei specimens in the comparison for the general nanhsiungchelyid morphotype is thus limited. A general nanhsiungchelyid morphotype as described below was found in all nanhsiungchelyid specimens studied (Basilemys sp., Hanbogdemys orientalis, Kharakhutulia kalandadzei, Nanhsiungchelyidae indet.).

\subsubsection{External cortex}

There is only a slight zonation of the external cortex into a more interior zone comprising ISF with rather homogeneous fibre bundle arrangement but generally lacking growth marks and a more external zone comprising ISF slightly dominated by structural fibre bundles that extend perpendicular to the external bone surface and which shows growth marks (Figs. 3a-d, 4a, b). Scattered primary osteons and simple or branching primary vascular canals are frequently found, but an extensive reticular pattern such as described above for adocid turtles was not encountered in the nanhsiungchelyids from Central Asia and Mongolia, except in specimens of Kharakhutulia kalandadzei. Growth marks of the more external part of the cortex are usually wavy and not parallel to each other, so that resorption of previously deposited tissue is common. The formation of the "pock-mark" ornamentation (seen as saddles and valleys in thin section) occurs through locally increased bone deposition of the cortical bone tissue. The most obvious feature in the more external part of the external cortex in Basilemys sp. is the orientation and high organisation of growth marks into a spindle-like pattern (Fig. 4a, b). The growth marks, which extend subparallel to each other at the transition from the deeper to the more superficial zone of the external cortex, progressively show a more wavy character, which becomes more and more pronounced towards the external bone surface. The wavy character of the growth marks depicts the typical "pock-mark" surface sculpturing in cross section and is thus tied to the development of the elaborate ornamentation pattern in this taxon (see also Scheyer and Anquetin, 2008). Additionally to the successive layering of the bone tissue, there occurs a lateral "shift" among adjacent layers. Through this "shift", the 

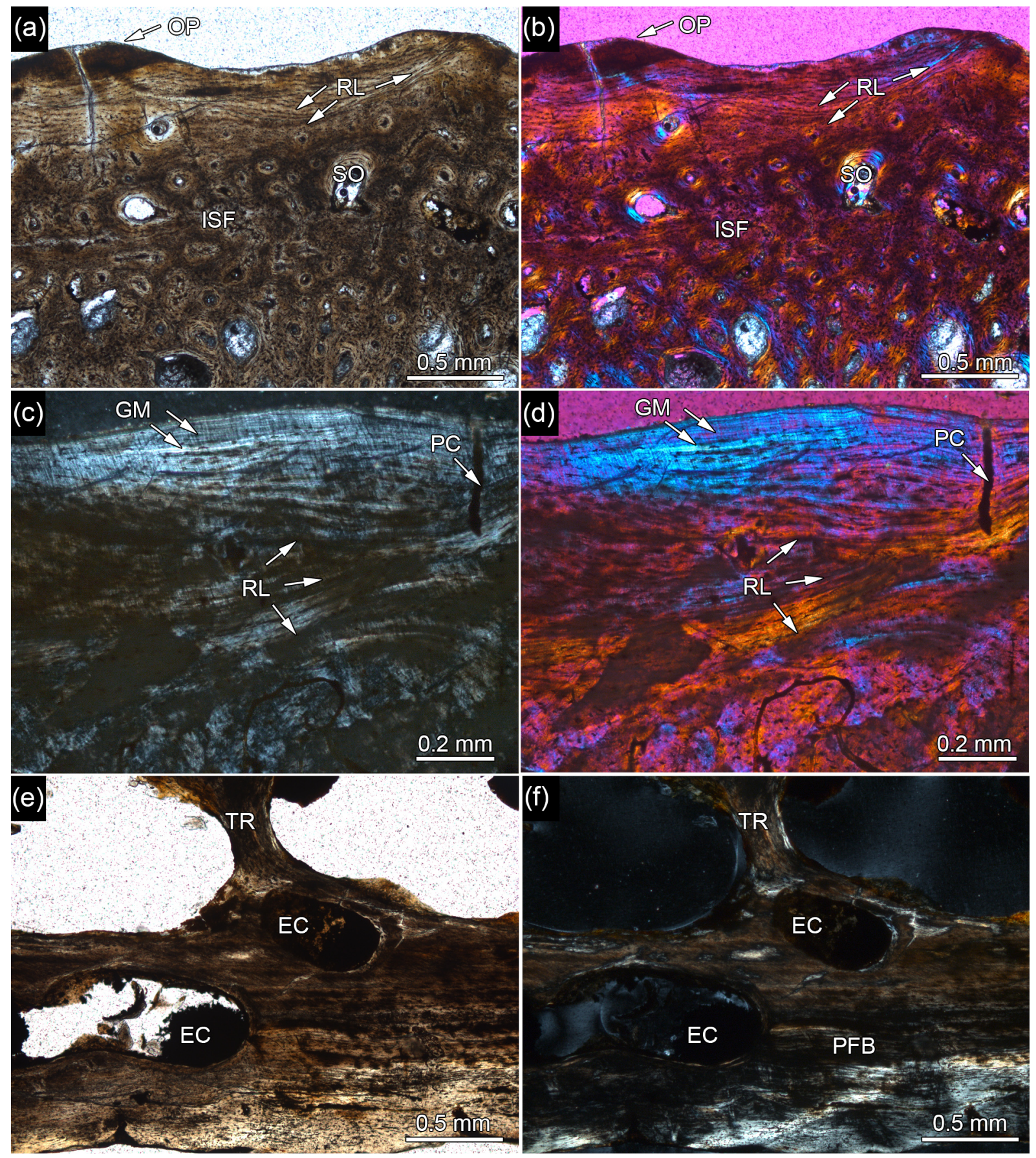

Figure 3. Bone histology of Nanhsiungchelyidae from Central Asia and Mongolia. Images (a) and (e) are in normal transmitted light, images (c) and (f) in polarised light, and (b) and (d) in polarised light applying a lambda compensator. (a, b) Close-up of external cortex of ZIN PH 38/80 (Nanhsiungchelyidae indet.). The more external zone shows growth marks, representing resorption lines in the cortical tissue. The more internal zone shows interwoven structural fibre bundles, vascularised by primary osteons and simple vascular canals. Note scattered secondary osteons. (c, d) Close-up of the external cortex of PIN 3458 (Hanbogdemys orientalis). Note presence of fibres extending perpendicular to the bone surface and subparallel growth marks in the external-most layers. Isolated primary vascular canals open up to the bone surface as small foramina. Note succession of resorption lines in the cortex. (e, f) Close-up of the interior cancellous bone and internal cortex of PIN 3458 (Hanbogdemys orientalis). The cortical parallel-fibred bone tissue is increasingly invaded by erosion cavities, only in parts lined with centripetally deposited secondary lamellar bone. Abbreviations: EC, erosion cavity; GM, growth mark; ISF, interwoven structural fibre bundles; OP, ornamentation pattern; PC, primary vascular canal; PFB, parallel-fibred bone; RL, resorption line; SO, secondary osteon; TR, trabecular bone. 

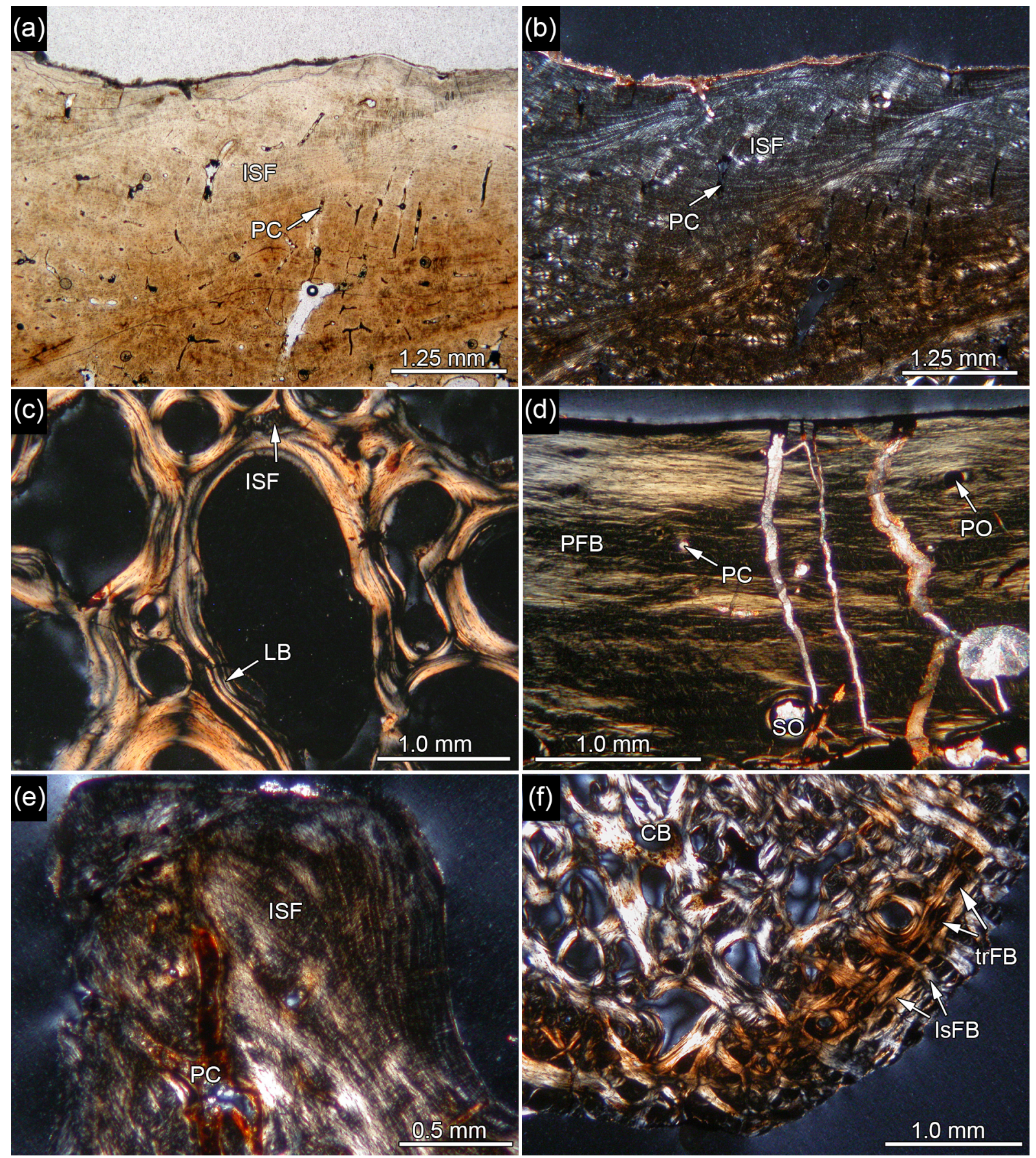

Figure 4. Shell bone histology of Basilemys sp. from North America. Image (a) is in normal transmitted light, and images (b-f) are in polarised light. (a, b) Section of the external cortex of the peripheral YPM 9703 showing characteristic spindle-shaped organisation of growth marks and the "pock-mark" sculpturing pattern of the bone surface. Note "lateral" shift between successive layers causing phasedelayed "saddle and valley" ornamentation pattern. (c) Close-up of the trabecular meshwork of interior cancellous bone of YPM 9703. Note interstitial primary bone matrix in trabecular nodes. (d) Close-up of the internal cortex of the peripheral shell fragment FM P27371. Parallel-fibred bone is vascularised by scattered primary osteons and simple vascular canals. (e) Close-up of the apical external cortex of the spiked osteoderm TMP 80.08.296, showing the external "pock-mark" sculpturing pattern and the spindle-shaped arrangement of bone tissue. (f) Close-up of the internal and lateral cortex of TMP 80.08.296. Note regular arrangement of transversely and longitudinally sectioned interwoven structural fibre bundles. Abbreviations: CB, cancellous bone; ISF, interwoven structural fibre bundles; LB, lamellar bone; lsFB, longitudinally sectioned fibre bundle; PC, primary vascular canal; PO, primary osteon, PFB, parallel-fibred bone; SO, secondary osteon; trFB, transversely sectioned fibre bundle. 
wavy saddle and valley arrangement is often phase-delayed, in that the next valley follows external to a saddle and vice versa. The result is a spindle-like structure of the bone tissue.

\subsubsection{Cancellous bone}

The cancellous bone (Figs. 3e, f, 4c) generally consists of short and slender bone trabeculae, which show various stages of remodelling. In shorter trabeculae and branching areas, large amounts of primary interstitial bone tissue, i.e. ISF, are present, whereas the trabecular walls consist of secondary lamellar bone. In the innermost parts of the bones, the length of trabeculae can be increased, thus leading to a more open trabecular meshwork with larger intertrabecular cavities. In the more slender trabeculae, the bone tissue is secondarily remodelled and the trabeculae thus consist mostly of lamellar bone.

\subsubsection{Internal cortex}

The internal cortical bone consists of parallel-fibred bone locally grading into lamellar bone (Figs. 3e, f, 4d). The bone tissue is weakly vascularised with scattered primary vascular canals and few primary osteons. Towards the cancellous bone, secondary osteons and erosion cavities are more frequently encountered. In the costals, coarse Sharpey's fibres insert into the cortical bone in moderate angles.

\subsubsection{Sutures}

The shell elements are generally well sutured; however, a strong incorporation of long fibre bundles, i.e. Sharpey's fibres, that extend perpendicular to the margins is not observed. The fibre bundles in the sutural bone are usually short and unobtrusive and appear to insert into the sutural bone tissue at low angles.

\subsubsection{Osteoderms}

The osteoderms of Basilemys sp. (TMP 2003.12.278, TMP 80.08.296) have a similar, sometimes even more pronounced, elaborate sculpturing pattern as seen in Basilemys sp. shell bones (Fig. 4e, f). The spindle-shaped structure in the external cortex is not always as conspicuous as in the shell bones though. The cancellous bone is composed of secondarily remodelled, usually short and slender bone trabeculae, with interstitial remains of primary ISF. The internal cortex constitutes coarsely fibred ISF, where fibre bundles are organised into a three-dimensional lattice (responsible for striations seen in outer morphology). Longitudinally sectioned fibre strands branch and anastomose around strands seen in cross section. In the latter, individual fibre bundles are separated by light delineations visible in polarised light.

\subsection{Trionychidae indet. remains from the middle Eocene Obayla Formation, Kazakhstan}

The sample including ZIN PH 3/75 and two shell fragments of ZIN PH 4/75 show a strongly weathered external bone surface and the typical diploe of turtle shell bone, with cortical bone layers framing interior cancellous bone (Fig. 5). Because of the weathered surface, these specimens were originally identified as belonging to "Adocus" kazachstanica (Danilov et al., 2011, mentioned and figured only specimen ZIN PH 2/75, a fragment of peripheral 3 from the same collection). According to Chkhikvadze (2010), there are five trionychid species known from the Obayala Formation. None of them was examined histologically prior to this study.

\subsubsection{External cortex}

The external cortex shows a more external zone, comprising the weathered sculpturing or ornamentation pattern of the external bone surface, and a more internal zone, dominated by a plywood-like pattern (Fig. 5a-d), which is virtually identical to that of other described Trionychidae specimens from North America and Europe (e.g. Scheyer et al., 2007, 2012; Vlachos et al., 2015). Within the plywood stack, adjacent plies are rotated to each other, i.e. to the ply on top and to the one below. Within the plies facing the reader, fibre bundles are organised in quadrangles, which are visible either in cross section (dark quadrangles with white delineations of individual bundles) or in longitudinal section (light quadrangles). At the saddles of the ornamentation, coarse Sharpey's fibres $(\mathrm{ShF})$ extend into the bone tissue in a fan-shaped arrangement.

\subsubsection{Cancellous bone}

Close to the cortices the bone tissue is coarse cancellous (Fig. 5e), but it becomes increasingly dominated by short and thick trabeculae in various stages of remodelling towards the centre of the shell bone. The trabeculae consist mainly of secondary lamellar bone but interstitial primary bone, i.e. ISF, is present as well. Intertrabecular cavities are usually horizontally oblong.

\subsubsection{Internal cortex}

The internal cortex consists of lamellar bone locally grading into parallel-fibred bone (Fig. 5f). It does not show the light and dark banding found in the adocid specimens. The tissue is vascularised with very few scattered primary vascular canals. Coarse ShF bundles extend in moderate angles over the whole compacta. 

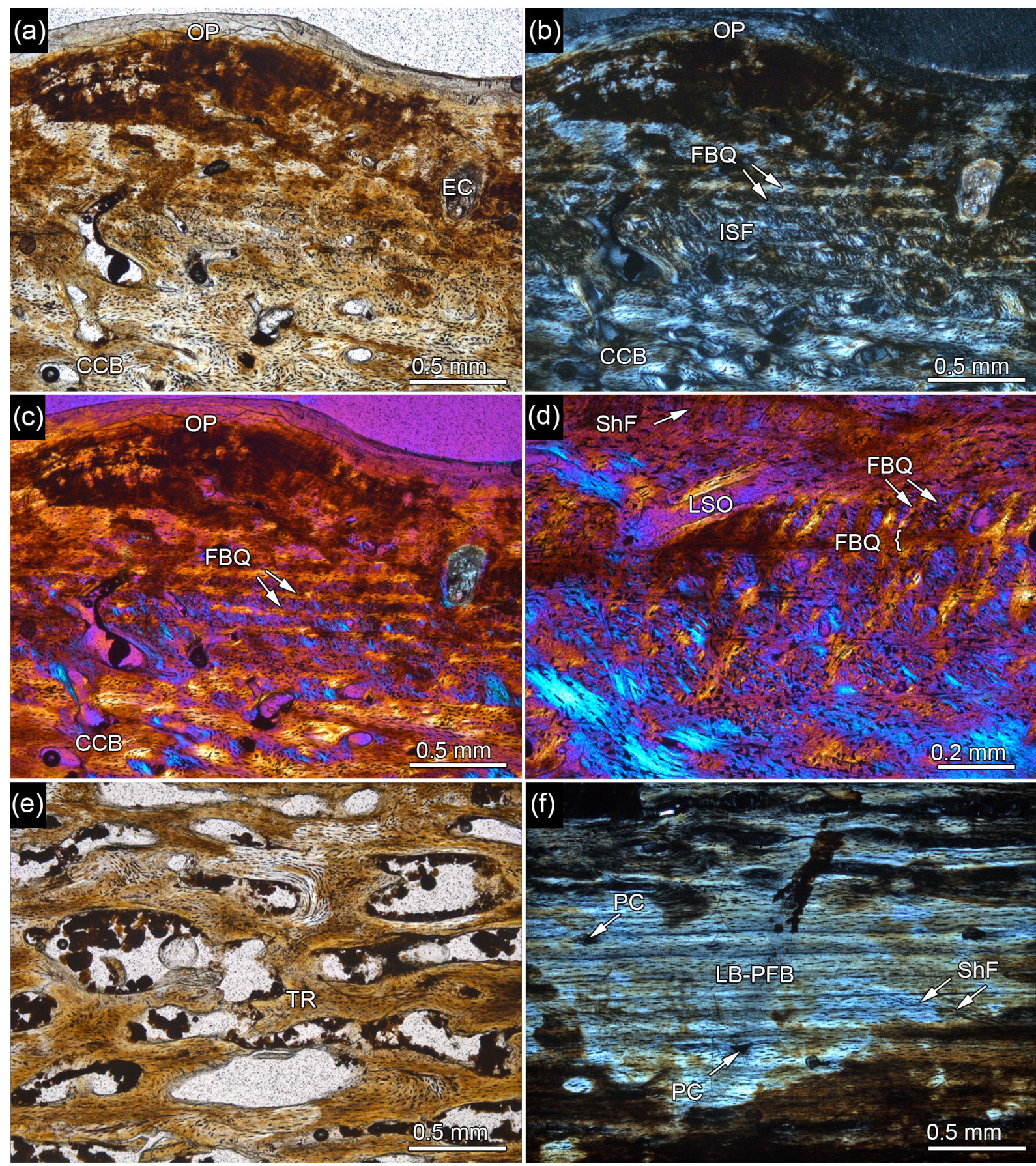

Figure 5. Bone histology of Trionychidae indet. (ZIN PH 3/75). Images (a) and (e) are in normal transmitted light, images (b) and (f) in polarised light, and (c) and (d) in polarised light applying a lambda compensator. (a-c) Close-up of the external cortex showing the plywoodlike system below the external ornamentation pattern. Note internal organisation of plies into fibre bundle quadrangles (see Scheyer et al., 2007), visible as alternating light and dark bundles (b) or yellow-orange and blue-violet bundles (c). Internal to the ply system the bone is coarsely cancellous. (d) Close up of the plywood-like system showing the longitudinally trending plies separating the plies, which show the alternating longitudinally sectioned (yellow-orange) and cross-sectioned (blue-violet) fibre bundle quadrangles. (e) Interior cancellous bone showing predominantly remodelled trabeculae and horizontally oblong intertrabecular cavities. (f) Close-up of the internal cortex showing lamellar zonal bone grading into parallel-fibred bone. Abbreviations: CCB, coarse cancellous bone; FBQ, fibre bundle quadrangles; ISF, interwoven structural fibre bundles; LSO, longitudinally sectioned secondary osteon; LZB-PFB, lamellar zonal bone-parallel-fibred bone; OP, ornamentation pattern; PC, primary vascular canal; PFB, parallel-fibred bone; ShF, Sharpey's fibres; TR, trabecular bone. 


\subsection{Trionychidae indet. remains from the Albian-Aptian of Dzun Bayan locality, Dundgov Aimag, Mongolia}

Similar to the trionychid samples mentioned in Sect. 3.3, the fragment of a costal ZIN PH 11/101 was originally assigned together with other specimens to Nanhsiungchelyidae indet. 3 (Danilov and Syromyatnikova, 2008). However, in ZIN PH $11 / 101$, the surface ornamentation is also strongly weathered and clear scute sulci as seen in costal fragment ZIN PH 9/101 (Danilov and Syromyatnikova, 2008, fig. 6B) are absent. The costal fragment ZIN PH 11/101 shows a diploe structure (Fig. 6a-e). This interior cancellous bone is framed by well-developed cortices. In contrast to the external cortex, the cancellous bone and internal cortex do not show any specialised microstructures.

\subsubsection{External cortex}

The external cortex can be subdivided into two zones: a more external part and a more internal part bordering the cancellous bone, which changes in thickness from the proximal to the distal end of the specimen. Both zones are vascularised by scattered primary vascular canals. Proximally, the more external zone shows a very homogeneous ISF bone tissue dominated by horizontally arranged fibres (often mirroring parallel-fibred bone) and, to a lesser degree, fibres bundles, which extend perpendicularly to the external bone surface. Sub-parallel growth marks within the ISF of the external zone basically mirror the wavy trend of the external ornamentation pattern. In the internal zone, the ISF show a peculiar organisation into a plywood-like system of dark and light bands (Fig. 6f, g). Towards proximal, the plywood-like system consists of a stack of thin plies, which lie deep to the massive external zone of ISF. Towards distal the plywood stack increases in thickness compared to the tapering off external zone and almost extends towards the external bone surface. This is achieved by an increase in thickness of the individual plies and not by an increase in ply numbers. Although the individual plies are difficult to trace through the whole fragment, they appear to be rather constant in number $(n \approx 12)$. As the plywood-like system is doubling in thickness from proximal $0.4 \mathrm{~mm}$ to distal $0.8 \mathrm{~mm}$, each ply increases from $\sim 0.03 \mathrm{~mm}(=30 \mu \mathrm{m})$ to $\sim 0.06 \mathrm{~mm}(=60 \mu \mathrm{m})$, whereas an internal organisation into fibre bundle quadrangles as in the plywood-like system in Trionychidae was not readily observable in ZIN PH 11/101.

\subsubsection{Cancellous bone}

The cancellous bone consists of a mixture of mostly thick and short primary and secondarily remodelled trabeculae with horizontally oblong to irregular inter-trabecular cavities (Fig. 6a-d).

\subsubsection{Internal cortex}

The internal cortex consists of parallel-fibred bone (Fig. 6b), vascularised by scattered primary vascular canals. At the purportedly distal end of the specimen, the trabecular organisation of the cancellous bone becomes increasingly substituted by a loose meshwork of coarse fibre bundles and vascular spaces, with fibre bundles extending predominantly perpendicular to the internal and lateral bone surface.

\section{Discussion}

The samples of Nanhsiungchelyidae and Adocidae from North America, Central Asia and Mongolia both show group-specific microstructures in the shell bones. In both families growth marks are visible as wavy lines in thin sections, extending subparallel to the external bone surface in adocids but not parallel or subparallel in nanhsiungchelyids. The highly peculiar and organised "spindle-shaped pattern" of ornamentation is restricted to the Late Cretaceous genus Basilemys from North America. The wavy growth marks in nanhsiungchelyids depicts the typical "pock-mark" surface sculpturing patterns. In adocids, the cancellous bone consists mostly of short and thick trabeculae, whereas the trabeculae are usually more slender in nanhsiungchelyids, likely reflecting varying shell thickness. The internal cortical bone consists of parallel-fibred bone (PFB) which grades locally into lamellar bone (except in North American samples of Adocus, showing only PFB). Secondary bone remodelling is more frequent in nanhsiungchelyids. Sharpey's fibres that extend perpendicular to the bone margins extending across subparallel growth marks are more commonly found in adocids (Fig. 1a, b), which is related to the generally lower external bone surface relief in this group compared to that of nanhsiungchelyids. The shared strong reticular vascularisation patterns in the external cortices of adocids and in the nanhsiungchelyid Kharakhutulia kalandadzei supports the position of the latter as a sister to all other Nanhsiungchelyidae.

These characters supplement the numerous differences in external shell morphology between adocids and nanhsiungchelyids (Danilov and Syromyatnikova, 2008: table 1 and references therein). However, there are also shared characters (e.g. morphogenesis of a regular ornamentation pattern; zonation of external cortex with rather homogeneous fine-fibred ISF in the more internal zone and a dominance of vertically oriented fibres in the ISF and the presence of growth marks in the more external zone), which corroborate the close relation of both groups within the stem-trionychian taxon Adocusia (Danilov and Parham, 2006). On the other hand, there are no osteohistological features that would indicate that one of those groups (either Nanhsiungchelyidae or Adocidae) would be more closely related to Trionychia than the other. 

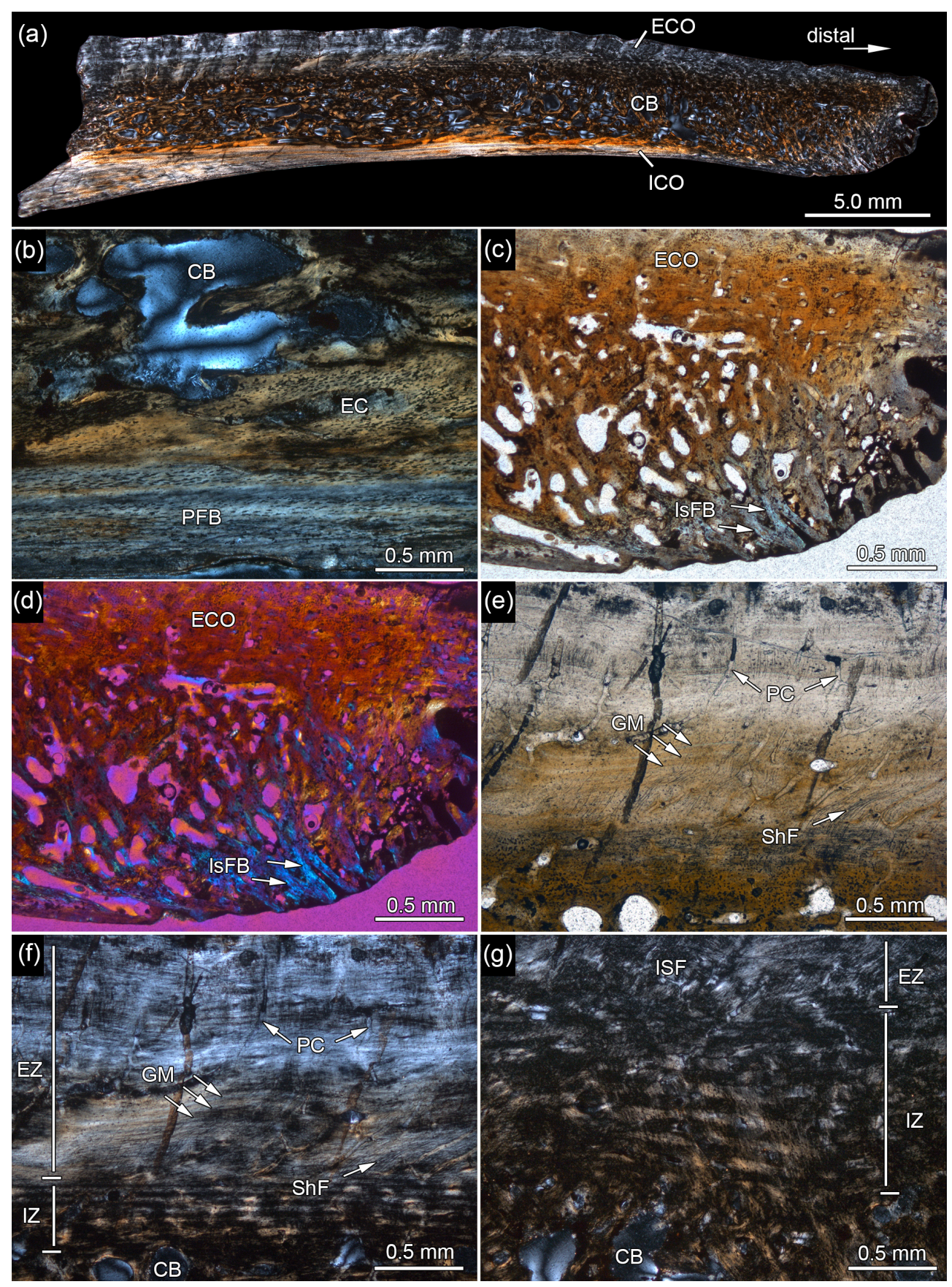

Figure 6. Bone histology of Trionychidae indet. (ZIN PH 11/101). Images (a), (b), (f), and (g) are in polarised light, images (c) and (e) in normal transmitted light, and image (d) in polarised light applying a lambda compensator. (a) Composite overview image assembled from several images and transferred on a black background. Note distally tapering of the internal cortex. (b) Close-up of cancellous bone and internal cortex, the latter being composed of parallel-fibred bone tissue. (c, d) Close-up of distal end of the specimen. The cancellous bone is subsequently substituted by a loose meshwork of longitudinal coarse fibre bundles. (e, f) Close-up of the proximal part of external cortex, showing a thick, more external zone of predominantly parallel trending interwoven structural fibres (mirroring parallel-fibred bone tissue arrangement), overlying a thin plywood-like system of the more internal zone. Note oblique coarser Sharpey's fibres extending over the plies. (g) Close-up of a more distally situated part the external cortex, where the individual plies of the more internal zone have increased to about twice the thickness seen in the more proximal part of the cortex. The interwoven structural fibre bundles of the more external zone show a more homogeneous distribution instead of dominance of horizontally arranged fibre bundles. Abbreviations: CB, cancellous bone; EC, erosion cavity; ECO; external cortex; EZ, more external zone; GM, growth mark; ICO, internal cortex; IZ, more internal zone, ISF, interwoven structural fibre bundles; lsFB, longitudinally sectioned fibre bundle; PC, primary vascular canal; PFB, parallel-fibred bone; ShF, Sharpey's fibres. 
Nanhsiungchelyid and adocid turtle shell bones share with carettochelyids and trionychids the external bone sculpturing, the diploe structure of shell bones, the presence of interwoven structural fibres in the external cortex, and the presence of parallel-fibred bone in the internal cortex (see Sect. 3.3 and 3.4; Scheyer et al., 2007, 2012; Delfino et al., 2010; Nakajima et al., 2017).

Furthermore, the presence of a plywood-like structure in ZIN PH 11/101 is insofar remarkable, as it represents the first record of trionychids from Dzun Bayan locality of Mongolia (see Danilov et al., 2014). This specimen might also indicate an important step in the acquisition and development of the cortical plywood-like system of trionychid turtles, which is typically a set of plies comprised of a complex fibre bundle quadrangle arrangement; these quadrangles are not observable in ZIN PH 11/101 (see Fig. 5). Instead, the fibres extending towards the external bone surface appear to be only loosely organised. Developmentally, ZIN PH 11/101 could thus fall between Kappachelys okurai Hirayama et al., 2013 from the Kitadani Formation (Hauterivian-Aptian) of Japan, lacking keratinous scute cover but retaining a ring of peripherals similar to carettochelyids (but showing some histological affinities to crown-trionychids), and indeterminate trionychid material from the Akaiwa Formation (Barremian-Aptian) of Japan and "Trionyx" kyrgyzensis from the Almyshik Formation (lower-middle Albian) of Kyrgyzstan, both of which unambiguously show the complex fibre bundle quadrangle arrangement in their plywood-like structure (Hirayama et al., 2013; Nakajima et al., 2017).

In conclusion, there were no apparent histological differences between the North American Adocus specimens from the Late Cretaceous and those from the Palaeocene, despite small variations in external bone sculpture patterns, nor were there large differences between genera Adocus, Ferganemys, and Shachemys (see Danilov et al. 2011, 2013b, for differences in the external bone sculpture pattern in these taxa). Those differences encountered in the extent and amount of the external cortical zones and the thicknesses of the transitional zone between external cortex and interior cancellous bone and that of the internal cortex were linked to the specimen-specific size and thickness of the shell fragment or different age of the animal. Our study thus increases the knowledge base on microanatomy and microstructures of adocusians and, as they are stem trionychians, serves as a comparative database for the crown groups Carettochelyidae and Trionychidae.

\section{Data availability}

All specimens used in the study are stored and freely accessible in the respective repositories noted in the text (see Table 1).
Author contributions. T. M. Scheyer and I. G. Danilov designed the study, E. V. Syromyatnikova and T. M. Scheyer sampled the specimens used, and T. M. Scheyer prepared the manuscript with contributions from all co-authors.

Competing interests. The authors declare that they have no conflict of interest.

Acknowledgements. Olivier Rieppel and William Simpson (Chicago), Pat Holroyd (Berkeley), Don Brinkman (Drumheller), Jaques Gauthier, Daniel Brinkman (New Haven) and Walter Joyce (formerly New Haven, now Fribourg), Tyler Lyson (Denver), and Vladimir B. Sukhanov (PIN) are thanked for access to specimens under their care. Some of the North American material mentioned in the present study was sampled in the process of the doctoral thesis of TMS (Scheyer, 2007; supervisor Martin Sander, Bonn, former DFG grant number SA469/15). Olaf Dülfer (Bonn) and Vivien Jaquier and Christian Kolb (Zurich) are thanked for various helps in preparing thin sections. This study was partly funded by the Swiss National Science Fund (number 31003A_146440 to T. M. Scheyer), the Russian Scientific Fund (grant no. 14-04-00015 to I. G. Danilov and E. V. Syromyatnikova; work on Cretaceous taxa from Central Asia) and Saint-Petersburg State University (grant no. 0.38.292.2015 to I. G. Danilov).

Edited by: F. Witzmann

Reviewed by: D. Brinkman and J. Sterli

\section{References}

Brinkman, D. B. and Nicholls, E. L.: New specimen of Basilemys praeclara Hay and its bearing on the relationships of the Nanhsiungchelyidae (Reptilia: Testudines), J. Paleont., 67, 1027-1031, 1993.

Brinkman, D. B. and Peng, J.-H.: A new species of Zangerlia (Testudines: Nanhsiungchelyidae) from the Upper Cretaceous redbeds at Bayan Mandahu, Inner Mongolia, and the relationships of the genus, Can. J. Earth Sci., 33, 526-540, 1996.

Brinkman, D. B., Tong, H.-Y., Li, H., Sun, Y., Zhang, J.-S., Godefroit, P., and Zhang, Z.-M.: New exceptionally well-preserved specimens of "Zangerlia"neimongolensis from Bayan Mandahu, Inner Mongolia, and their taxonomic significance, C.R. Palevol, 14, 577-587, doi:10.1016/j.crpv.2014.12.005, 2015.

Chkhikvadze, V. M.: Tertiary Turtles of the Zaissan Depression, Metsniereba Publishers, Tbilisi, 100 pp., 1973 (in Russian).

Chkihkvadze, V. M.: Paleogenowyje cerepachi SSSR [Paleogene turtles of the USSR; Neogene Schildkröten der UdSSR], Tiflis (Mezniereba), 96 pp., 1990.

Chkhikvadze, V. M.: An annotated catalogue of Paleogene, Neogene and Recent turtles of Northern Eurasia [In Russian], Georgian National Museum - Proceedings of the Natural and Prehistoric Section, 2, 96-113, 2010.

Danilov, I. G. and Parham, J. F.: A redescription of 'Plesiochelys' tatsuensis from the Late Jurassic of China, with comments on the antiquity of the crown clade Cryptodira, J. Vertebr. Paleontol., 26, 573-580, 2006. 
Danilov, I. G. and Syromyatnikova, E. V.: New materials on turtles of the family Nanhsiungchelyidae from the Cretaceous of Uzbekistan and Mongolia, with a review of the nanhsiungchelyid record in Asia, Proc. Zool. Inst. RAS, 213, 3-25, 2008.

Danilov, I. G. and Syromyatnikova, E. V.: Phylogeny of the extinct turtle clade Adocusia, Gaffney Turtle Symposium (17-18 October 2009, Drumheller, Canada), Drumheller, Canada, 44-51, 2009a.

Danilov, I. G. and Syromyatnikova, E. V.: Phylogenetic analysis of turtles of the superfamily Adocoidea [In Russian], in: Modern Paleontology: Classical and New Methods - 2009, Paleontological Institute of the Russian Academy of Sciences, Moscow, edited by: Rozanov, A. Y., Lopatin, A. V., and Parkhaev, P. Y., 67-82, 2009b.

Danilov, I. G. and Vitek, N. S.: Cretaceous trionychids of Asia: an expanded review of their record and biogeography [published 16 August 2012], in: Morphology and Evolution of Turtles. Proceedings of the Gaffney Turtle Symposium (2009) in Honor of Eugene S Gaffney. Vertebrate Paleobiology and Paleoanthropology Series [ISBN 978-94-007-4308-3; 577 pp.], edited by: Brinkman, D. B., Holroyd, P. A., and Gardner, J. D., Springer, Dordrecht, 419-438, 2013.

Danilov, I. G., Sukhanov, V. B., and Syromyatnikova, E. V.: New materials on turtles of the family Adocidae with a review of the adocid record in Asia, Proc. Zool. Inst. RAS, 315, 101-132, 2011.

Danilov, I. G., Sukhanov, V. B., and Syromyatnikova, E. V.: Redescription of Zangerlia dzamynchondi (Testudines: Nanhsiungchelyidae) from the Late Cretaceous of Mongolia, with a reassessment of the phylogenetic position and relationships of Zangerlia [published 16 August 2012], in: Morphology and Evolution of Turtles. Proceedings of the Gaffney Turtle Symposium (2009) in Honor of Eugene S Gaffney. Vertebrate Paleobiology and Paleoanthropology Series [ISBN 978-94-007-4308-3; 577 pp.], edited by: Brinkman, D. B., Holroyd, P. A., and Gardner, J. D., Springer, Dordrecht, 407-417, 2013a.

Danilov, I. G., Syromyatnikova, E. V., Skutschas, P. P., Kodrul, T. M., and Jin, J.: The first 'true' Adocus (Testudines, Adocidae) from the Paleocene of Asia, J. Vertebr. Paleontol., 33, 10711080, doi:10.1080/02724634.2013.768254, 2013 b.

Danilov, I. G., Hirayama, R., Sukhanov, V. B., Suzuki, S., Watabe, M., and Vitek, N. S.: Cretaceous soft-shelled turtles (Trionychidae) of Mongolia: new diversity, records and a revision, J. Syst. Palaeontol., 12, 799-832, doi:10.1080/14772019.2013.847870, 2014.

Delfino, M., Scheyer, T. M., Fritz, U., and Sánchez-Villagra, M. R.: An integrative approach to examining a homology question: shell structures in soft-shelled turtles, Biol. J. Linn. Soc., 99, 462-476, doi:10.1111/j.1095-8312.2009.01356.x, 2010.

de Spix, J. B.: Animalia nova sive species novae Testudinum et Ranarum, quas in itinere per Brasiliam annis MDCCCXVII - MDCCCXX jussu et auspiciis Maximiliani Josephi I. Bavariae Regis suscepto collegit et descripsit, Leipzig, 53 pp., 1824.

Eberth, D. A.: The geology, in: Dinosaur Provincial Park. A Spectacular Ancient Ecosystem Revealed, edited by: Currie, P. J. and Koppelhus E. B., Indiana University Press, Bloomington, Indiana, 54-82, 2005.

Francillon-Vieillot, H., Buffrénil, V. de, Castanet, J., Géraudie, J., Meunier, F. J., Sire, J. Y., Zylberberg, L., and de Ricqlès, A.: Mi- crostructure and mineralization of vertebrate skeletal tissues, in: Skeletal Biomineralization: Patterns, Processes and Evolutionary Trends, edited by: Carter, J. G., Van Nostrand Reinhold, New York, 471-530, 1990.

Hay, O. P.: Bibliography and catalogue of the fossil vertebrata of North America, USGS Bull., 179, 1-868, 1902.

Hirayama, R.: Preliminary report of the fossil turtles from the Kitadani Formation (Early Cretaceous) of the Tetori Group of Katsuyama, Fukui Prefecture, Central Japan, Mem. Fukui Prefect. Dinosaur Mus., 1, 29-40, 2002 (in Japanese).

Hirayama, R., Sakurai, K., Chitoku, T., Kawakami, G., and Kito, N.: Anomalochelys angulata, an unusual land turtle of Family Nanhsiungchelyidae (Superfamily Trionychoidea; Order Testudines) from the Upper Cretaceous of Hokkaido, North Japan, Russ. J. Herpetol., 8, 127-138, 2001.

Hirayama, R., Isaji, S., and Hibino, T.: Kappachelys okurai gen. et sp. nov., a new stem soft-shelled turtle from the Early Cretaceous of Japan [published 16 August 2012], in: Morphology and Evolution of Turtles. Proceedings of the Gaffney Turtle Symposium (2009) in Honor of Eugene S Gaffney, Vertebrate Paleobiology and Paleoanthropology Series [ISBN 978-94-007-4308-3; 577 pp.], edited by: Brinkman, D. B., Holroyd, P. A., and Gardner, J. D., Springer, Dordrecht, 179-185, 2013.

Hummel, K.: Die fossilen Weichschildkröten (Trionychia), Geol. Pal. Abh., 16, 359-487, 1929.

Hutchison, J. H.: Diversity of Cretaceous turtle faunas of Eastern Asia and their contribution to the turtle faunas of North America, Paleontol. Soc. Korea, Spec. Publ., 4, 27-38, 2000.

Joyce, W. G.: A review of the fossil record of turtles of the clade Pan-Carettochelys, Peabody Mus. Nat His. Yale Univ. Bull., 55, 3-33, doi:10.3374/014.055.0102, 2014.

Joyce, W. G. and Norell, M. A.: Zangerlia ukhaachelys, new species, a nanhsiungchelyid turtle from the late Cretaceous of Ukhaa Tolgod, Mongolia, Am. Mus. Novit., 3481, 1-19, 2005.

Joyce, W. G., Parham J. F., and Gauthier, J. A.: Developing a protocol for the conversion of rank-based taxon names to phylogenetically defined clade names, as exemplified by turtles, J. Paleont., 78, 989-1013, doi:10.1666/00223360(2004)078<0989:DAPFTC>2.0.CO;2, 2004.

Joyce, W. G., Rabi, M., Clark, J. M., and Xu, X.: A toothed turtle from the Late Jurassic of China and the global biogeographic history of turtles, BMC Evolutionary Biology, 16, 236, 29 pp., doi:10.1186/s12862-016-0762-5, 2016.

Kuznetsov, V. V.: A freshwater turtle from the Senonian of northeastern Cis-Aralia, Paleontologicheskiy Zhurnal, 4, 498-500, 1976 (in Russian).

Meylan, P. A. and Gaffney, E. S.: The skeletal morphology of the Cretaceous cryptodiran turtle, Adocus, and the relationships of the Trionychoidea, Am. Mus. Novit., 2941, 1-60, 1989.

Młynarski, M.: Zangerlia testudinimorpha n. gen., n. sp., a primitive land tortoise from the Upper Cretaceous of Mongolia, Palaeontol. Polonica, 27, 85-92, 1972.

Młynarski, M.: Testudines, Handbuch der Paläoherpetologie, Teil 7, in: Handbook of Paleoherpetology, Part 7, Gustav Fischer Verlag, Stuttgart, 130, 1976.

Nakajima, Y., Danilov, I. G., Hirayama, R., Sonoda, T., and Scheyer, T. M.: Morphological and histological evidences for the oldest known softshell turtles from Japan, J. Vertebr. Paleontol., in press, 2017. 
Nessov, L. A.: Skull morphology of the Early Cretaceous turtle belonging to the family Adocidae, in: Gerpetol. Sborhik, Trudy Zool. Inst., Akad. Nauk. USSR, edited by: Ananjeva, N. B., Borkin, K. L., and Darevsky, I. S., 75-80, 1977 (in Russian).

Nessov, L. A.: About phylogenetic relationships and history of distribution of some families of continental turtles, Zhizn' na drevnikh kontinentakh, ee stanovleniye i razvitiye. Trudy XXIII sessii Vsesoyuznogo Paleontologicheskogo Obshchestva, Izdatel'stvo 'Nauka', Leningrad, 133-141, 1981 (in Russian).

Nessov, L. A. and Khosatzky, L. I.: Freshwater turtle from the Early Cretaceous of Fergana, Ezhegodnik Vsesoyuznogo Paleontologicheskogo Obshchestva, 20, 248-262, 1977 (in Russian).

Nessov, L. A. and Krasovskaya, T. B.: Changes in the composition of turtles assemblages of Late Cretaceous of Middle Asia, Vestnik Leningradskogo Gosudarstvennogo Universiteta, 3, 15-25, 1984 (in Russian).

Scheyer, T. M.: Comparative bone histology of the turtle shell (carapace and plastron): implications for turtle systematics, functional morphology, and turtle origins, MathematischNaturwissenschaftliche Fakultät, Doctoral Thesis, University of Bonn, Germany, 343 pp., available at: http://hss.ulb.uni-bonn.de/ 2007/1229/1229.htm, 2007.

Scheyer, T. M. and Anquetin, J.: Bone histology of the Middle Jurassic turtle shell remains from Kirtlington, Oxfordshire, England, Lethaia, 41, 85-96, doi:10.1111/j.15023931.2007.00044.x, 2008.

Scheyer, T. M. and Sánchez-Villagra, M. R.: Carapace bone histology in the giant pleurodiran turtle Stupendemys geographicus: phylogeny and function, Acta Palaeontol. Pol., 52, 137-154, 2007.

Scheyer, T. M., Sander, P. M., Joyce, W. G., Böhme, W., and Witzel, U.: A plywood structure in the shell of fossil and living softshelled turtles (Trionychidae) and its evolutionary implications, Org. Divers. Evol., 7, 136-144, doi:10.1016/j.ode.2006.03.002, 2007.

Scheyer, T. M., Mörs, T., and Einarsson, E.: First record of soft-shelled turtles (Cryptodira, Trionychidae) from the Late Cretaceous of Europe, J. Vertebr. Paleontol., 32, 1027-1032, doi:10.1080/02724634.2012.685036, 2012.

Seeley, H. G.: Note on Psephophorus polygonus, v. Meyer, a new type of chelonian reptile allied to the leathery turtle, Q. J. Geol. Soc. London, 36, 406-413, 1880.

Sukhanov, V. B.: Mesozoic turtles of Middle and Central Asia, in: The Age of Dinosaurs in Russia and Mongolia, edited by: Benton, M. J., Shishkin, M. A., Unwin, D. M., and Kurochkin, E. N., Cambridge University Press, Cambridge, 309-367, 2000.

Sukhanov, V. B. and Narmandakh, P.: Turtles of the Basilemys group (Chelonia, Dermatemydidae) in Asia. Trudy Sovmestnoj Sovetsko-Mongol'skoj Paleontologičeskoj Ekspedicii, 2, 94101, 1975 (in Russian).

Sukhanov, V. B. and Narmandakh, P.: New taxa of Mesozoic turtles from Mongolia, Fossil Turtle Research, Vol. 1, Russ. J. Herpetol., 13 (Suppl.), 119-127, 2006.
Sukhanov, V. B., Danilov, I. G., and Syromyatnikova, E. V.: The description and phylogenetic position of a new nanhsiungchelyid turtle from the Late Cretaceous of Mongolia, Acta Palaeontol. Pol., 53, 601-614, 2008.

Syromyatnikova, E. V.: Turtles of the genus Ferganemys Nessov et Khosatzky, 1977 (Adocidae): shell morphology and phylogenetic position, Proc. Zool. Inst. RAS, 315, 38-52, 2011.

Syromyatnikova, E. V. and Danilov, I. G.: New material and a revision of the turtles of the genus Adocus (Adocidae) from the Late Cretaceous of Middle Asia and Kazakhstan, Proc. Zool. Inst. RAS, 313, 74-94, 2009.

Syromyatnikova, E. V. and Danilov, I. G.: New material and phylogenetic position of Adocus bostobensis, a poorly known adocid turtle from the Late Cretaceous of Kazakhstan, Proc. Zool. Inst. RAS, 317, 195-201, 2013.

Syromyatnikova, E. V., Danilov, I. G., and Sukhanov, V. B.: A redescription and phylogneetic position of Adocus planus, an adocid turtle from the Late Cretaceous of Mongolia, Proc. Zool. Inst. RAS, 316, 380-391, 2012.

Syromyatnikova, E. V., Danilov, I. G., and Sukhanov, V. B.: The skeletal morphology and phylogenetic position of Adocus amtgai, an adocid turtle from the Late Cretaceous of Mongolia, Cret. Res., 45, 155-173, doi:10.1016/j.cretres.2013.07.006, 2013.

Syromyatnikova, E. V., Scheyer, T. M., and Danilov, I. G.: Bone histology of adocusian turtles from Asia and North America, J. Vertebr. Paleontol., Program and Abstracts, 234, 2016.

Tong, H. and Mo, J.: Jiangxichelys, a new nanhsiungchelyid turtle from the Late Cretaceous of Ganzhou, Jiangxi Province, China, Geol. Mag., 147, 981-986, doi:10.1017/S0016756810000671, 2010.

Tong, H., Claude, J., Naksri, W., Sutheethorn, V., Buffetaut, E., Khansubha, S., Wongko, K., and Yuangdetkla, P.: Basilochelys macrobios $\mathrm{n}$. gen. and n. sp., a large cryptodiran turtle from the Phu Kradung Formation (latest Jurassic-earliest Cretaceous) of the Khorat Plateau, NE Thailand, Geol. Soc. London Spec. Publ., 315, 153-173, doi:10.1144/SP315.12, 2009.

Tong, H., Xu, L., Buffetaut, E., Zhang, X., and Jia, S.: A new nanhsiungchelyid turtle from the Late Cretaceous of Neixiang, Henan Province, China, Ann. Paléontol., 98, 303-314, doi:10.1016/j.annpal.2012.08.001, 2012.

Tong, H., Li, L., and Ouyang, H.: A revision of Sinaspideretes wimani Young \& Chow, 1953 (Testudines: Cryptodira: Trionychoidae) from the Jurassic of the Sichuan Basin, China, Geol. Mag., 151, 600-610, doi:10.1017/S0016756813000575, 2014.

Vlachos, E., Cerda, I., and Tsoukala, E.: The first record of a soft-shelled turtle (Testudines: Pan-Trionychidae) from southern Balkans (Pliocene, Gefira, N. Greece) and new information from bone histology, The Science of Nature, 102, doi:10.1007/s00114015-1295-2, 2015.

Yeh, H.-K..: A new Cretaceous turtle of Nanhsiung, northern Kwangtung. Vertebr. PalAsiat., 10, 191-200, 1966.

Young, C. C. and Chow, M. C.: New fossil reptiles from Szechuan, China. Sci. Sin., 2, 216-243, 1953. 